\title{
Title: Quantitative Cardiac MRI
}

\section{Abstract:}

Cardiac MRI has become an indispensable imaging modality in the investigation of patients with suspected heart disease. It has emerged as the gold standard test for cardiac function, volumes and mass and allows non-invasive tissue characterization and the assessment of myocardial perfusion. Quantitative MRI already has a key role in the development and incorporation of machine learning in clinical imaging, potentially offering major improvements in both workflow efficiency and diagnostic accuracy. As the clinical applications of a wide range of quantitative cardiac MRI techniques are being explored and validated, we are expanding our capabilities for earlier detection, monitoring and risk stratification of disease, potentially guiding personalized management decisions in various cardiac disease models. In this article we review established and emerging quantitative techniques, their clinical applications, highlight novel advances and appraise their clinical diagnostic potential.

Keywords: quantitative, mapping, perfusion, machine learning, tissue characterization 


\section{Introduction}

Cardiac Magnetic Resonance Imaging (MRI) is now indispensable for many common clinical scenarios arising during the care of cardiac patients. Not only it is established as the gold standard test for cardiac function, myocardial volumes and mass (1), but is also the imaging modality of choice for myocardial tissue characterization. In recent years, a series of technical developments have transformed diagnostic capabilities by introducing new quantitative evaluation methods for these and other areas such as perfusion, 4D flow and myocardial mechanics. Combined with an expansion of cardiac MRI services and the wider availability of new imaging sequences, quantitative cardiac MRI enhances our understanding of cardiac pathology, exploring the link between biology and clinical manifestation of cardiac disease. Here, we review established and emerging quantitative techniques, their clinical applications, highlight novel advances and appraise their clinical diagnostic potential.

\section{Quantitative evaluation of cardiac volumes and function}

\section{Cardiac MRI as the gold standard in cardiac segmentation}

Quantitative segmentation of the cardiac chambers is a key step in the assessment of cardiovascular (CV) disease. The measurement of ventricular volumes, mass and systolic function allows identification and grading of pathologies, prognostic assessment and the monitoring of changes under therapy. For example, myocardial wall thickness in hypertrophic cardiomyopathy $(\mathrm{HCM})$ and the ejection fraction $(\mathrm{EF})$ in heart failure act as key parameters for defibrillator or resynchronisation therapy $(2,3)$. However, different imaging modalities yield different results (4). With the use of cutpoints for clinical decisions (e.g. above or below $35 \%$ ejection fraction, $15 \mathrm{~mm}$ or 
$30 \mathrm{~mm}$ wall thickness), can have major reclassification implications resulting in widely different clinical decisions (5). Two- and three- dimensional (2D and 3D) transthoracic echocardiography (TTE) and MRI delineate contours with high precision in phantoms (ex-vivo) (6) but both TTE methods measure lower ventricular dimensions in-vivo compared with MRI (7). There is a technical limitation of echocardiography to distinguish trabeculae (and low blood flow yielding low contrast) from compacted myocardium. The more flow independent image quality of steady state free precession (SSFP) cardiac MRI allows better endocardial definition and a more three-dimensional approach with fewer geometric assumptions, making it the gold standard for measuring ventricular volumes and ejection fraction (8). The issue of "normal range" of trabeculations has been a matter of debate, with different criteria used between various imaging modalities (9). How trabeculae, and for that matter papillary muscles are considered (part of the LV blood pool or part of LV mass) alters LV mass and volumes but also derived parameters eg EF (12). There is no uniformly accepted convention as to how these should be measured and analyzed. The most important thing to do is to ensure the per-patient analysis is the same as that used to derive reference ranges. As papillary muscles can hypertrophy in some diseases (Fabry, hypertrophic cardiomyopathy), for accuracy reasons (papillary muscles are made of muscle, not blood), we prefer to treat them and trabeculae as myocardium not blood. There is some concern however that this reduces measurement precision.

Clinically it is just as important to reliably detect change over time - measurement precision (repeatability), in terms of initiating and monitoring treatment. Similarly, from a research perspective, test precision determines trial sizes and power calculations for 
sample size estimations. Precision is also particularly important as there is no easily applied gold standard for volumes and mass in human ventricular measurement, but precision can be measured (through test: retest; coefficient of variation) (Table 1). Ventricular segmentation with cardiac MRI - our most accurate and precise method for cardiac structure evaluation - also has variability. The complex geometry of the heart as well as the anatomical and imaging variability pose a challenge. Contouring is tedious, costly and even with quality control and training investment, variability persists. Measured chamber size values vary with pulse sequence (SSFP vs spoiled gradient echo (13)), 2D or 3D acquisition and analysis method (14). The latter includes software platform, mathematic formulae (e.g. Simpson's rule), contour detection method (e.g. fully manual or semi-automated contour delineation), measurements made in long-axis or short-axis views, treatment of long axis function, whether papillary muscles/trabeculae are counted as muscle or blood pool, and reader experience. Attempts to minimise variability through standardisation of have only been partial (15).

\section{Novel means of segmentation in Cardiac MRI}

Manual delineation of ventricular contours even by experienced MRI readers has intraobserver and interobserver variation (20) as well as interscan variability, reducing precision. Semi-automatic or fully automatic segmentation can remove some of this variability. These methods can be: $(A)$ image-driven if they identify voxels belonging to the blood pool, myocardium or appendage by assessing the difference in signal intensity or (B) model-driven if they are based on strong prior knowledge, like that from cardiac atlases or statistical shape models, and are trained in manually 
annotated data (18). There are several types of image-driven techniques, but thresholding, region-growing, clustering and voxel classification are the most widely used. The choice of one method over the other is not straightforward and depends on a number of factors, including constraints of the protocol and the specificities of the disease being studied. A comparison of these different methods is difficult as the ground-truth is also difficult to define. Model-driven fully automated segmentation tools based on artificial intelligence (Al) might be particularly useful (Figure 1). Convolutional neural network (CNN) approaches to ventricular segmentation started with a 2015 Kaggle competition, where 1000 datasets were provided. The open source code was subsequently repurposed by many (19) (20). The larger and the more diverse the dataset is (different diseases, magnets, pulse sequences, image quality), the more generalizable the model becomes. The latest approaches are moving on from comparison with clinician contours (e.g. using Dice scores) to similarly diverse test: retest datasets for precision. Best current results suggest non-inferiority to expert human performance (21). Such approaches if rolled-out to global healthcare systems could completely remove intra- and inter-observer variability, standardize global practice and save time. There are however challenges in the future: training datasets will need to reflect global practice and all diseases and evolve over time as techniques change. In addition, they permit robust linkage of normal reference ranges to current analysis methods (as the normal range can be re-computed for each model improvement), and lower the barriers to using more representative population reference ranges. Furthermore, should models become super-human (i.e. improved measurement precision) then new biology may become detectable in existing studies 
with reanalysis, improve prognostic power as new studies would need fewer patients to detect an effect, and interval scanning will have smaller detectable differences.

\section{Going beyond ejection fraction}

Global systolic function measurements like EF can be insensitive to early cardiac diseases. Regional myocardial dysfunction may occur before global impairment so deformation imaging detects early contractile dysfunction (22). Systolic myocardial deformation occurs longitudinally (basal-apical shortening), circumferentially (shortening along the circular perimeter) and radially (thickening of the myocardium towards the centre of the cavity) and is measured as strain, a measure of the degree of deformation of a segment. Different diseases affect these differently, either globally or regionally - for example, ischaemia is mainly subendocardial and if coronary artery disease related, territorial; amyloid is apex sparing; Fabry, dystrophinopathies and others affects the basal inferolateral wall first.

Tissue Doppler imaging and Speckle Tracking have been widely used in echocardiography for measuring strain, but these are heavily dependent on operator and technical aspects (e.g. frame rate, acquisition angle) (23). Cardiac MRI strain imaging uses either specific pulse sequences during acquisition (tagging, phase velocity mapping, displacement encoding with stimulated echoes [DENSE], strainencoding) or post-processing analysis of standard cine images (23) such as Feature Tracking (FT) (Figure 2) (24). Although DENSE provides images with good spatial resolution, clinical experience is limited. Tagging is a more validated tool for myocardial deformation assessment and has better reproducibility than FT, but its 
interpretation can be affected by spatial resolution and tag fading through the cardiac cycle. FT has the advantages of not requiring additional time in the scanner for image acquisition, as it can use most conventionally acquired SSFP cines with minimal annotation and processing time. However, FT remains dependent on image quality and does not account for through-plane motion (23). Overall the adoption barriers are lower for FT than other techniques for myocardial deformation to guide clinical care.

The clinical applications of myocardial deformation imaging are numerous. Strain analysis can identify segments that will recover after an acute myocardial infarct (25) and can detect small contractility changes during dobutamine stress testing (26). Patients with hypertrophic cardiomyopathy have abnormal strain in hypertrophied segments regardless of late gadolinium enhancement (27). Strain can also detect cardiotoxicity in patients undergoing chemotherapy before left ventricular (LV) EF impairment (28) and early cardiac involvement in rare diseases (29) (Figure 2).

Nonetheless, standardization is needed. Different vendors, pulse sequences and software account for the difficulty in attaining normal ranges for strain in cardiac MRI (24). Similar to LVEF, manual contouring variability must be considered, but Al might also be able to minimize these. It is worth highlighting that unlike speckle-tracking echocardiography, where the use if strain has been shown to have prognostic implications in multiple cardiac pathologies (30), similar data on the prognostic utility of feature tracking with CMR are currently lacking. 


\section{Quantitative tissue characterization using parametric mapping}

\section{techniques}

Our ability to evaluate myocardial tissue by exploiting the magnetic properties of various myocardial structures has had a major impact in clinical cardiology. Late gadolinium enhancement (LGE) techniques using post-contrast T1-weighted sequences have been used to evaluate focal myocardial processes such fibrosis, and have been extensively used in ischemic and non-ischemic heart disease (31). Similarly, T2-weighted sequences enabled evaluation of edema and inflammation (32). Both of these techniques are limited by the qualitative nature of the assessment enabled as both rely on the relative difference in the relaxation properties of the diseased versus the distal "healthy" myocardium. Cardiac MRI parametric mapping techniques allow the spatial visualization of quantitative changes in the myocardium based on changes in myocardial T1, T2, T2* and extra-cellular volume (ECV) (33), enabling evaluation of diffuse changes within the myocardium.

\section{T1 mapping and its clinical applications}

T1 mapping involves the acquisition of a series of co-registered images at different times of $\mathrm{T} 1$ recovery, allowing the pixel-wise illustration of an absolute $\mathrm{T} 1$ relaxation time through the generation of a color-encoded map (34). The use of T1 mapping as an imaging biomarker for tissue characterization is based on the principle that changes in longitudinal relaxation time ( $\mathrm{T} 1)$ reflect changes in the water content as well as the local molecular environment (35), therefore quantitative evaluation of T1 relaxation allows identification of various pathophysiological processes affecting the myocardium (36) (Figure 3). 
Since the original description of $\mathrm{T} 1$ relaxation measurements by Look and Locker in 1970 (37), a number of methods have been described and clinically used, including the Modified Look-Locker Inversion recovery (MOLLI) pulse sequence (38), Shortened MOdified Look-Locker Inversion recovery (ShMOLLI) (39), saturation recovery single-shot acquisition (SASHA) sequence (40) and saturation pulse prepared heart-rate-independent inversion recovery (SAPPHIRE) (41). Among these, MOLLI appears to be the most widely validated and commonly used sequence (Table 2). Despite similar reproducibility in vivo measurements between T1 mapping sequences, it appears that inversion-recovery (IR) based techniques (MOLLI, ShMOLLI) have more clinical potential as inversion recovery permits greater sampling of a recovery curve and therefore greater separation of $\mathrm{T} 1$ species than saturation recovery (SR); and the heart rate variability independence of SR can be accounted for in IR approaches during reconstruction. SR approaches are more magnetization transfer insensitive than IR so are technically more accurate compared to a slow spin echo T1 ground truth, but it is not clear whether this is clinically important as the primary purpose of mapping is to differentiate health from disease rather than accurately measure $\mathrm{T} 1(42,43)$.

T1 mapping can be used for both native (pre-contrast) and post-contrast $\mathrm{T} 1$ relaxation measurements. Native T1 mapping can provide quantification of the composite signal from both the cellular (including myocytes) and extracellular space with pathological effect size being reflected by greatest $\mathrm{T} 1$ shortening to greatest lengthening: iron (shortest), fat, athletic training, normal, fibrosis, amyloid, edema (longest) (36). T1 mapping as a potential imaging biomarker is therefore useful, particularly for the rare 
diseases. It adds value to LGE and may differentiate some conditions with similar imaging phenotypes and allow earlier disease detection (44) with prognostic implications (Table 2)

Post contrast $\mathrm{T} 1$ relaxation reflects changes in the extracellular space, but also renal clearance, hematocrit and total body contrast volume of distribution so calculation of extracellular volume fraction (ECV) is preferable. Unlike native $\mathrm{T} 1, \mathrm{ECV}$ represents a physiological parameter, is less sequence and field strength dependent. It is a measurement of the free water, myocardial water between cells (myocardial and red blood cells). This may reflect fibrosis in some circumstances, and has been correlated with histological estimates of collagen volume fraction in some diseases (47), but may reflect amyloid or extracellular edema in other circumstances. Small changes can also be seen with myocardial capillary vasodilatation, or potentially capillary rarefaction (48). A synthetic ECV can also be calculated by estimating the hematocrit from blood T1 - the more anemic, the longer blood T1 becomes -, providing an immediate method of ECV derivation and display as a map (49). For most patients, increase in ECV predominantly reflects changes in collagen volume fraction, a final common pathway in many disorders with prognostic impact (50), potentially incremental to LGE (51). Despite its well established diagnostic and prognostic capacity (63), LGE misses diffuse disease and correlates less well with collagen in the presence of diffuse fibrosis (54). 


\section{T2 mapping and its clinical applications}

T2 mapping is an additional promising technique for tissue characterization. The main biological determinant of $\mathrm{T} 2$ relaxation is the amount and macromolecular state of water and $\mathrm{T} 2$ is found to reflect mainly myocardial edema. If there is also myocyte death (troponin release, a blood biomarker), this is likely to reflect myocardial inflammation - a pathophysiological process that may be responsive to specific treatments (Table 3). Two types of mapping sequences are often used for T2 mapping, including a single-shot turbo spin-echo (TSE) sequence with multiple echoes and bright-blood T2-preparation pulse-based sequences (55). Newer sequences enabling acquisition of dark blood myocardial T2 maps, potentially allowing improved definition of the blood-myocardium border have recently been reported (56).

T2 mapping has been extensively studied in the diagnosis and risk stratification of patients with myocarditis. It not only improves diagnostic accuracy, but also predicts outcomes $(57,58)$ with higher T2 values predicting major cardiovascular events and hospitalization. T2 mapping is also being explored in other inflammatory diseases including acute cardiac allograft rejection (57), sarcoidosis (59), systemic lupus erythematosus (60) and acute infarction, with the potential of reducing the need for invasive cardiac biopsy in some scenarios. Elevated T2 mapping values compared to healthy controls have also been demonstrated in subsets of dilated cardiomyopathy (58) and aortic stenosis $(61,62)$, potentially enabling disease sub-stratification (63). The combination of T2 and T1 mapping offers incremental information in some diseases, including patients with cancer-treatment related cardio-toxicity, differentiating between early and later cardio-toxicity by attempting to differentiate chronic interstitial fibrosis from edema (64). 


\section{Quantification of $\mathbf{T 2}^{\star}$ relaxation time and its clinical application}

In clinical medicine, $\mathrm{T}^{*}$ had an immediate impact in clinical processes and patient outcomes in the management of iron-overload cardiomyopathies. T2* relaxation is the decay of transverse magnetization in the presence of static magnetic field inhomogeneity and is particularly sensitive to the presence of iron. Calculation of myocardial T2* involves the acquisition of serial images of a mid-ventricular short axis view at increasing echo times (TE), allowing the formation of an exponential decay curve of signal intensity vs TE $\left(y=K e^{-T E / T 2^{*}}\right.$ where $K$ represents a constant, and $y$ represents the image signal intensity) (78). Quantification of tissue iron overload with $\mathrm{T}^{*}$ was shown to strongly correlate with liver (67) and reasonably with myocardial iron (68) from histology data. Cardiac $\mathrm{T}^{*}$ below $10 \mathrm{~ms}$ is associated with the risk of developing heart failure and arrhythmias (69) in patients with thalassemia major - a condition which represents a clear human model of tissue iron overload. The introduction of $\mathrm{T}^{*}$ tied to therapeutic escalation resulted in an impressive reduction $(>60 \%)$ in UK deaths from thalassemia $(70)$. The ability for serial quantitative assessment of tissue iron overload has allowed $\mathrm{T}^{*}$ to serve as an outcome measure in trials evaluating different iron chelator therapies (71) and to become the standard of care in chronically transfused patients, allowing targeted intensification of treatment before the development of heart failure (Figure 5$). R 2^{*}$ maps $\left(1 / T 2^{*}\right)$ are potentially more user friendly as $\mathrm{R} 2^{*}$ linearly correlates with iron burden and the maps extenuate abnormality, for example Figure 5 , where blue is normal $(<50 \mathrm{~Hz})$ and any pixels $>50 \mathrm{~Hz}$ are green / yellow / red highlighting iron burden.

\section{Quantitative perfusion cardiac MRI}


Revascularisation only improves symptoms if a stenosis is causing ischemia. Performing percutaneous coronary intervention $(\mathrm{PCl})$ on non-flow limiting lesions worsens outcomes (72) and revascularizing myocardium with higher ischemic burdens is more beneficial (73). Non-invasive ischemia testing is therefore the gateway to invasive angiography. Cardiac MRI with stress perfusion has high sensitivity and specificity for the detection of flow limiting coronary artery disease (86) and uses nonionizing radiation. However, there are disadvantages. It is subjective and operator dependent. Windowing the images can result in different interpretation of ischemia. There is also the theoretical possibility of missing "balanced" ischemia due to triple vessel disease. Quantitative perfusion therefore may have advantages. This is shown by the PET literature where patients with reduced perfusion reserve or stress flow on quantification have worse outcomes whether they have occlusive coronary artery disease or other conditions such as dilated cardiomyopathy and hypertrophic cardiomyopathy (78).

Semi-quantitative approaches to perfusion cardiac MRI have been performed, all involving measuring the signal intensity $(\mathrm{SI})$ in the myocardium during the first pass of a gadolinium based contrast agent. Examples include the contrast enhancement ratio (CER), the myocardial to LV upslope index and the upslope integral ratio. The contrast enhancement ratio requires the baseline and the peak SI in the area of interest. By using the formula (Sl $\left.\right|_{\text {peak-Sl }}$ baseline)/Slbaseline, perfusion can be compared semiquantitatively in different areas of the myocardium. The CER can be accurate for the detection of CAD against truth standards of PET and invasive angiography in expert centres (78). The myocardial to LV upslope index is calculated by dividing the initial upslope of the myocardial SI-time curve by the initial upslope of the LV SI-time curve 
in the regions of interest. The upslope integral ratio is the area under the curve of the myocardial Sl-time curve following baseline adjustment. The main problem of semiquantitative methods is firstly that microsphere studies show they underestimate higher flow rates (79) with the CER and myocardial to LV upslope index becoming non-linear above $\sim 1 \mathrm{ml} / \mathrm{g} / \mathrm{min}$ flow or $\sim 3 \mathrm{ml} / \mathrm{g} / \mathrm{min}$ for the upslope integral ratio and secondly, they require extensive, expert operator post-processing limiting clinical adoption.

Fully quantitative techniques have been developed. Absolute quantification requires the measurement of both the arterial input function (AIF, highly concentrated gadolinium) and myocardial signal changes (lower gadolinium concentration) but accurate simultaneous measurement in these two domains requires too much compromise(80). Two main approaches overcome this: the "dual bolus" and "dual sequence" techniques. Once the AIF is accurately measured there is a deconvolution step in which the measured contrast concentration in the myocardium can be converted to an absolute MBF (81). Both the dual bolus and dual sequence techniques have shown good correlation with absolute MBF measured using microspheres (82).

The dual bolus approach involves the administration of initial low dose contrast (for AIF measurement) then usual higher dose (for myocardial response). This is clinically cumbersome. The dual sequence approach uses an additional low resolution gradient echo sequence acquired immediately after the $\mathrm{R}$ wave optimised for the AIF followed by a long recovery delay, higher resolution gradient echo or balanced SSFP readout to measure the myocardial signal (83). This approach is more straightforward but 
requires onerous post-processing (eg manually tracing 50 stress and rest measurements on 3 LV slices), impeding clinical adoption.

Automation of these is now possible (84). One solution is "Perfusion Mapping" (85), a dual sequence approach with inline analysis through the Gadgetron framework (86). In brief, AIF images are acquired with a dual sequence approach (T2* loss minimized by using a short readout, wide bandwidth and short duration RF pulse with 2 echoes to permit $\mathrm{T}^{*}$ decay correction). Following latest generation respiratory motion correction (MOCO), the blood pool is automatically segmented using machine learning to extract the AIF and signal converted to gadolinium concentration using Bloch simulation. For myocardial imaging (3 slices, parallel imaging, high resolution), MOCO, coil normalisation and conversion of signal to $\mathrm{Gd}$ concentration is performed. These images are then used to calculate absolute MBF for each voxel of tissue using a model (here the blood tissue exchange (BTEX) model) by solving partial differential equations (87). Advantages of the approach is that a single bolus of contrast is required, the sequence is free-breathing and quantitative perfusion maps are outputted inline alongside the raw perfusion images with no user input required, increasing the likelihood of clinical adoption. Technical validation has been performed against PET and coronary angiography, including invasive in-vivo direct flow measurement (88-91). However, currently this sequence is only available in around 40 centres (as of February 2019). Other approaches to pixel-wise perfusion quantification have been proposed with initial promising results (92).

An alternative to first pass perfusion is myocardial arterial spin labeling (ASL) where a radiofrequency pulse to arterial blood modifies its longitudinal magnetization, "labeling" 
it (93). This blood flows into the myocardium, and if two sets of images, one with and one without the ASL are taken and subtracted, myocardial blood flow can be derived without gadolinium and with relatively simple modelling. ASL is used in brain imaging (94) but cardiac and respiratory motion and reduced SNR require more work to permit effective clinical deployment in cardiac MRI. A variety of different approaches are being explored (95)(96), but scans are still long. There remain issues with heart rate variability and validation is in in the domain of correlation with other technical methods rather than patient related outcomes (97).

\section{Conclusion}

Quantitative cardiac MRI is rapidly evolving within cardiac imaging, and is shaping the way we understand and diagnose cardiac disease. It represents a prime example of how new technological developments can have a direct impact on our understanding of pathophysiology of disease, translating to changes in clinical practice and patient outcomes. Quantitative MRI has a key role in the development and incorporation of machine learning in clinical imaging, potentially offering major improvements in both workflow efficiency and diagnostic accuracy with new biomarkers becoming clinically available. Finally, as the clinical applications of these techniques are explored and validated, it is likely that quantitative cardiac MRI techniques will serve as non-invasive imaging tools capable of earlier detection, monitoring and risk stratification of disease, potentially guiding personalized management decisions in various cardiac disease models. 


\section{References:}

1. Lorenz CH, Walker ES, Morgan VL, Klein SS, Graham TP. Normal human right and left ventricular mass, systolic function, and gender differences by cine magnetic resonance imaging. J Cardiovasc Magn Reson. 1999;1(1):7-21.

2. O'Mahony C, Akhtar MM, Anastasiou Z, Guttmann OP, Vriesendorp PA, Michels M, et al. Effectiveness of the 2014 European Society of Cardiology guideline on sudden cardiac death in hypertrophic cardiomyopathy: a systematic review and meta-analysis. Heart. 2018 Oct 26;

3. European Society of Cardiology (ESC), European Heart Rhythm Association (EHRA), Brignole M, Auricchio A, Baron-Esquivias G, Bordachar P, et al. 2013 ESC guidelines on cardiac pacing and cardiac resynchronization therapy: the task force on cardiac pacing and resynchronization therapy of the European Society of Cardiology (ESC). Developed in collaboration with the European Heart Rhythm Association (EHRA). Europace. 2013 Aug;15(8):1070-118.

4. Wood PW, Choy JB, Nanda NC, Becher H. Left ventricular ejection fraction and volumes: it depends on the imaging method. Echocardiography. 2014;31(1):87-100.

5. Pellikka PA, She L, Holly TA, Lin G, Varadarajan P, Pai RG, et al. Variability in Ejection Fraction Measured By Echocardiography, Gated Single-Photon Emission Computed Tomography, and Cardiac Magnetic Resonance in Patients With Coronary Artery Disease and Left Ventricular Dysfunction. JAMA Netw Open [Internet]. 2018 Aug 31

6. Polte CL, Lagerstrand KM, Gao SA, Lamm CR, Bech-Hanssen O. Quantification of Left Ventricular Linear, Areal and Volumetric Dimensions: A Phantom and in Vivo Comparison of 2-D and Real-Time 3-D Echocardiography with Cardiovascular Magnetic Resonance. Ultrasound Med Biol. 2015 Jul;41(7):1981-90.

7. Rigolli M, Anandabaskaran S, Christiansen JP, Whalley GA. Bias associated with left ventricular quantification by multimodality imaging: a systematic review and meta-analysis. Open Heart. 2016;3(1):e000388.

8. Zamorano JL, Bax JJ, Rademakers FE. Evaluation of Systolic and Diastolic LV Function. The ESC Textbook of Cardiovascular Imaging. New York: Springer; 2010. 307-320 p.

9. Choi Y, Kim SM, Lee S-C, Chang S-A, Jang SY, Choe YH. Quantification of left ventricular trabeculae using cardiovascular magnetic resonance for the diagnosis of left ventricular noncompaction: evaluation of trabecular volume and refined semi-quantitative criteria. J

Cardiovasc Magn Reson. 2016 04;18(1):24.

10. Jenni R, Oechslin E, Schneider J, Attenhofer Jost C, Kaufmann PA. Echocardiographic and pathoanatomical characteristics of isolated left ventricular non-compaction: a step towards classification as a distinct cardiomyopathy. Heart. 2001 Dec;86(6):666-71.

11. Petersen SE, Selvanayagam JB, Wiesmann F, Robson MD, Francis JM, Anderson RH, et al. Left ventricular non-compaction: insights from cardiovascular magnetic resonance imaging. J Am Coll Cardiol. 2005 Jul 5;46(1):101-5.

12. Chuang ML, Gona P, Hautvast GLTF, Salton CJ, Blease SJ, Yeon SB, et al. Correlation of trabeculae and papillary muscles with clinical and cardiac characteristics and impact on CMR measures of LV anatomy and function. JACC Cardiovasc Imaging. 2012

Nov;5(11):1115-23.

13. Alfakih K, Plein S, Thiele H, Jones T, Ridgway JP, Sivananthan MU. Normal human left and right ventricular dimensions for MRI as assessed by turbo gradient echo and steadystate free precession imaging sequences. J Magn Reson Imaging. 2003 Mar;17(3):323-9.

14. Petersen SE, Aung N, Sanghvi MM, Zemrak F, Fung K, Paiva JM, et al. Reference ranges 
for cardiac structure and function using cardiovascular magnetic resonance (CMR) in Caucasians from the UK Biobank population cohort. J Cardiovasc Magn Reson [Internet]. 2017 Feb 3

15. Suinesiaputra A, Bluemke DA, Cowan BR, Friedrich MG, Kramer CM, Kwong R, et al. Quantification of LV function and mass by cardiovascular magnetic resonance: multi-center variability and consensus contours. J Cardiovasc Magn Reson. 2015 Jul 28;17:63.

16. Catalano O, Antonaci S, Opasich C, Moro G, Mussida M, Perotti M, et al. Intra-observer and interobserver reproducibility of right ventricle volumes, function and mass by cardiac magnetic resonance. J Cardiovasc Med (Hagerstown). 2007 Oct;8(10):807-14.

17. Luijnenburg SE, Robbers-Visser D, Moelker A, Vliegen HW, Mulder BJ, Helbing WA. Intra-observer and interobserver variability of biventricular function, volumes and mass in patients with congenital heart disease measured by CMR imaging. Journal of Cardiovascular Magnetic Resonance. 2009 Jan 28;11(1):P100.

18. Peng P, Lekadir K, Gooya A, Shao L, Petersen SE, Frangi AF. A review of heart chamber segmentation for structural and functional analysis using cardiac magnetic resonance imaging. MAGMA. 2016 Apr;29(2):155-95.

19. Ngo TA, Lu Z, Carneiro G. Combining deep learning and level set for the automated segmentation of the left ventricle of the heart from cardiac cine magnetic resonance. Med Image Anal. 2017;35:159-71.

20. Kaggle Second Annual Data Science Bowl [Internet]. 2018. Available from: https://www.kaggle.com/c/second-annual-data-science-bowl/

21. Bai W, Sinclair M, Tarroni G, Oktay O, Rajchl M, Vaillant G, et al. Automated cardiovascular magnetic resonance image analysis with fully convolutional networks. J Cardiovasc Magn Reson. 2018 14;20(1):65.

22. Lamacie MM, Thavendiranathan P, Hanneman K, Greiser A, Jolly M-P, Ward R, et al. Quantification of global myocardial function by cine MRI deformable registration-based analysis: Comparison with MR feature tracking and speckle-tracking echocardiography. Eur Radiol. 2017 Apr;27(4):1404-15.

23. Scatteia A, Baritussio A, Bucciarelli-Ducci C. Strain imaging using cardiac magnetic resonance. Heart Fail Rev. 2017;22(4):465-76.

24. Claus P, Omar AMS, Pedrizzetti G, Sengupta PP, Nagel E. Tissue Tracking Technology for Assessing Cardiac Mechanics: Principles, Normal Values, and Clinical Applications. JACC Cardiovasc Imaging. 2015 Dec;8(12):1444-60.

25. McComb C, Carrick D, McClure JD, Woodward R, Radjenovic A, Foster JE, et al. Assessment of the relationships between myocardial contractility and infarct tissue revealed by serial magnetic resonance imaging in patients with acute myocardial infarction. Int J Cardiovasc Imaging. 2015;31(6):1201-9.

26. Schneeweis C, Qiu J, Schnackenburg B, Berger A, Kelle S, Fleck E, et al. Value of additional strain analysis with feature tracking in dobutamine stress cardiovascular magnetic resonance for detecting coronary artery disease. J Cardiovasc Magn Reson. 2014 Oct 1;16:72.

27. Aletras AH, Tilak GS, Hsu L-Y, Arai AE. Heterogeneity of intramural function in hypertrophic cardiomyopathy: mechanistic insights from MRI late gadolinium enhancement and high-resolution displacement encoding with stimulated echoes strain maps. Circ Cardiovasc Imaging. 2011 Jul;4(4):425-34.

28. Nakano S, Takahashi M, Kimura F, Senoo T, Saeki T, Ueda S, et al. Cardiac magnetic resonance imaging-based myocardial strain study for evaluation of cardiotoxicity in breast cancer patients treated with trastuzumab: A pilot study to evaluate the feasibility of the method. Cardiol J. 2016;23(3):270-80. 
29. Vijapurapu R, Nordin S, Baig S, Liu B, Rosmini S, Augusto J, et al. Global longitudinal strain, myocardial storage and hypertrophy in Fabry disease. Heart. 2018 Oct 3;

30. Potter E, Marwick TH. Assessment of Left Ventricular Function by Echocardiography: The Case for Routinely Adding Global Longitudinal Strain to Ejection Fraction. JACC: Cardiovascular Imaging. 2018 Feb 5;11(2 Part 1):260-74.

31. Kim RJ, Fieno DS, Parrish TB, Harris K, Chen EL, Simonetti O, et al. Relationship of MRI delayed contrast enhancement to irreversible injury, infarct age, and contractile function. Circulation. 1999 Nov 9;100(19):1992-2002.

32. Eitel I, Friedrich MG. T2-weighted cardiovascular magnetic resonance in acute cardiac disease. J Cardiovasc Magn Reson. 2011 Feb 18;13:13.

33. Messroghli DR, Moon JC, Ferreira VM, Grosse-Wortmann L, He T, Kellman P, et al. Clinical recommendations for cardiovascular magnetic resonance mapping of T1, T2, T2* and extracellular volume: A consensus statement by the Society for Cardiovascular Magnetic Resonance (SCMR) endorsed by the European Association for Cardiovascular Imaging (EACVI). J Cardiovasc Magn Reson. 2017 Oct 9;19(1):75.

34. Moon JC, Messroghli DR, Kellman P, Piechnik SK, Robson MD, Ugander M, et al. Myocardial T1 mapping and extracellular volume quantification: a Society for Cardiovascular Magnetic Resonance (SCMR) and CMR Working Group of the European Society of Cardiology consensus statement. J Cardiovasc Magn Reson. 2013 Oct 14;15:92.

35. Kellman P, Hansen MS. T1-mapping in the heart: accuracy and precision. J Cardiovasc Magn Reson. 2014 Jan 4;16:2.

36. Haaf P, Garg P, Messroghli DR, Broadbent DA, Greenwood JP, Plein S. Cardiac T1 Mapping and Extracellular Volume (ECV) in clinical practice: a comprehensive review. J Cardiovasc Magn Reson. 2016 Nov 30;18(1):89.

37. Look DC, Locker DR. Time saving in measurement of NMR and EPR relaxation times. Rev Sci Instrum. 1970;(41:250-1.).

38. Messroghli DR, Radjenovic A, Kozerke S, Higgins DM, Sivananthan MU, Ridgway JP. Modified Look-Locker inversion recovery (MOLLI) for high-resolution T1 mapping of the heart. Magn Reson Med. 2004 Jul;52(1):141-6.

39. Piechnik SK, Ferreira VM, Dall'Armellina E, Cochlin LE, Greiser A, Neubauer S, et al. Shortened Modified Look-Locker Inversion recovery (ShMOLLI) for clinical myocardial T1mapping at 1.5 and 3 T within a 9 heartbeat breathhold. J Cardiovasc Magn Reson. 2010 Nov 19;12:69.

40. Chow K, Flewitt JA, Green JD, Pagano JJ, Friedrich MG, Thompson RB. Saturation recovery single-shot acquisition (SASHA) for myocardial T(1) mapping. Magn Reson Med. 2014 Jun;71(6):2082-95.

41. Weingärtner S, Akçakaya M, Basha T, Kissinger KV, Goddu B, Berg S, et al. Combined saturation/inversion recovery sequences for improved evaluation of scar and diffuse fibrosis in patients with arrhythmia or heart rate variability. Magn Reson Med. 2014 Mar;71(3):1024-34.

42. Roujol S, Weingärtner S, Foppa M, Chow K, Kawaji K, Ngo LH, et al. Accuracy, precision, and reproducibility of four T1 mapping sequences: a head-to-head comparison of MOLLI, ShMOLLI, SASHA, and SAPPHIRE. Radiology. 2014 Sep;272(3):683-9.

43. Child N, Suna G, Dabir D, Yap M-L, Rogers T, Kathirgamanathan M, et al. Comparison of MOLLI, shMOLLLI, and SASHA in discrimination between health and disease and relationship with histologically derived collagen volume fraction. Eur Heart J Cardiovasc Imaging. 2018 01;19(7):768-76.

44. Thompson RB, Chow K, Khan A, Chan A, Shanks M, Paterson I, et al. $\mathrm{T}_{1}$ mapping with 
cardiovascular MRI is highly sensitive for Fabry disease independent of hypertrophy and sex. Circ Cardiovasc Imaging. 2013 Sep;6(5):637-45.

45. Reinstadler SJ, Stiermaier T, Liebetrau J, Fuernau G, Eitel C, de Waha S, et al. Prognostic Significance of Remote Myocardium Alterations Assessed by Quantitative Noncontrast T1 Mapping in ST-Segment Elevation Myocardial Infarction. JACC Cardiovasc Imaging. 2018 Mar;11(3):411-9.

46. Lee H, Park J-B, Yoon YE, Park E-A, Kim H-K, Lee W, et al. Noncontrast Myocardial T1 Mapping by Cardiac Magnetic Resonance Predicts Outcome in Patients With Aortic Stenosis. JACC Cardiovasc Imaging. 2018 Jul;11(7):974-83.

47. Sibley CT, Noureldin RA, Gai N, Nacif MS, Liu S, Turkbey EB, et al. T1 Mapping in cardiomyopathy at cardiac MR: comparison with endomyocardial biopsy. Radiology. 2012 Dec;265(3):724-32.

48. Lurz JA, Luecke C, Lang D, Besler C, Rommel K-P, Klingel K, et al. CMR-Derived Extracellular Volume Fraction as a Marker for Myocardial Fibrosis: The Importance of Coexisting Myocardial Inflammation. JACC Cardiovasc Imaging. 2018 Jan;11(1):38-45. 49. Fent GJ, Garg P, Foley JRJ, Swoboda PP, Dobson LE, Erhayiem B, et al. Synthetic Myocardial Extracellular Volume Fraction. JACC Cardiovasc Imaging. 2017 Nov;10(11):1402-4.

50. Zhuang B, Sirajuddin A, Wang S, Arai A, Zhao S, Lu M. Prognostic value of T1 mapping and extracellular volume fraction in cardiovascular disease: a systematic review and metaanalysis. Heart Fail Rev. 2018 Sep;23(5):723-31.

51. Vita T, Gräni C, Abbasi SA, Neilan TG, Rowin E, Kaneko K, et al. Comparing CMR Mapping Methods and Myocardial Patterns Toward Heart Failure Outcomes in Nonischemic Dilated Cardiomyopathy. JACC Cardiovasc Imaging. 2018 Nov 8;

52. Klem I, Shah DJ, White RD, Pennell DJ, van Rossum AC, Regenfus M, et al. Prognostic value of routine cardiac magnetic resonance assessment of left ventricular ejection fraction and myocardial damage: an international, multicenter study. Circ Cardiovasc Imaging. 2011 Nov;4(6):610-9.

53. Kim RJ, Wu E, Rafael A, Chen EL, Parker MA, Simonetti O, et al. The use of contrastenhanced magnetic resonance imaging to identify reversible myocardial dysfunction. $\mathrm{N}$ Engl J Med. 2000 Nov 16;343(20):1445-53.

54. Parsai C, O'Hanlon R, Prasad SK, Mohiaddin RH. Diagnostic and prognostic value of cardiovascular magnetic resonance in non-ischaemic cardiomyopathies. J Cardiovasc Magn Reson. 2012 Aug 2;14:54.

55. Giri S, Chung Y-C, Merchant A, Mihai G, Rajagopalan S, Raman SV, et al. T2 quantification for improved detection of myocardial edema. J Cardiovasc Magn Reson. 2009 Dec 30;11:56.

56. Wang C, Jang J, Neisius U, Nezafat M, Fahmy A, Kang J, et al. Black blood myocardial T2 mapping. Magn Reson Med. 2019 Jan;81(1):153-66.

57. Vermes E, Pantaléon C, Auvet A, Cazeneuve N, Machet MC, Delhommais A, et al. Cardiovascular magnetic resonance in heart transplant patients: diagnostic value of quantitative tissue markers: T2 mapping and extracellular volume fraction, for acute rejection diagnosis. J Cardiovasc Magn Reson. 2018 Aug 27;20(1):59.

58. Spieker M, Katsianos E, Gastl M, Behm P, Horn P, Jacoby C, et al. T2 mapping cardiovascular magnetic resonance identifies the presence of myocardial inflammation in patients with dilated cardiomyopathy as compared to endomyocardial biopsy. Eur Heart J Cardiovasc Imaging. 2018 01;19(5):574-82.

59. Crouser ED, Ono C, Tran T, He X, Raman SV. Improved detection of cardiac sarcoidosis 
using magnetic resonance with myocardial T2 mapping. Am J Respir Crit Care Med. 2014 Jan $1 ; 189(1): 109-12$.

60. Winau L, Hinojar Baydes R, Braner A, Drott U, Burkhardt H, Sangle S, et al. Highsensitive troponin is associated with subclinical imaging biosignature of inflammatory cardiovascular involvement in systemic lupus erythematosus. Ann Rheum Dis. 2018 Nov;77(11):1590-8.

61. Fehrmann A, Treutlein M, Rudolph T, Rudolph V, Weiss K, Giese D, et al. Myocardial T1 and T2 mapping in severe aortic stenosis: Potential novel insights into the pathophysiology of myocardial remodelling. Eur J Radiol. 2018 Oct;107:76-83.

62. Kvernby S, Rönnerfalk M, Warntjes M, Carlhäll C-J, Nylander E, Engvall J, et al. Longitudinal changes in myocardial $\mathrm{T} 1$ and $\mathrm{T} 2$ relaxation times related to diffuse myocardial fibrosis in aortic stenosis; before and after aortic valve replacement. J Magn Reson Imaging. 2018 Feb 23;

63. Mordi I, Carrick D, Bezerra H, Tzemos N. T1 and T2 mapping for early diagnosis of dilated non-ischaemic cardiomyopathy in middle-aged patients and differentiation from normal physiological adaptation. Eur Heart J Cardiovasc Imaging. 2016 Jul;17(7):797-803. 64. Haslbauer JD, Lindner S, Valbuena-Lopez S, Zainal H, Zhou H, D’Angelo T, et al. CMR imaging biosignature of cardiac involvement due to cancer-related treatment by T1 and T2 mapping. Int J Cardiol. 2018 Oct 11;

65. Anderson LJ, Holden S, Davis B, Prescott E, Charrier CC, Bunce NH, et al. Cardiovascular T2-star $(\mathrm{T} 2 *$ ) magnetic resonance for the early diagnosis of myocardial iron overload. Eur Heart J. 2001 Dec;22(23):2171-9.

66. Westwood M, Anderson LJ, Firmin DN, Gatehouse PD, Charrier CC, Wonke B, et al. A single breath-hold multiecho $\mathrm{T} 2 *$ cardiovascular magnetic resonance technique for diagnosis of myocardial iron overload. J Magn Reson Imaging. 2003 Jul;18(1):33-9.

67. Wood JC, Enriquez C, Ghugre N, Tyzka JM, Carson S, Nelson MD, et al. MRI R2 and R2* mapping accurately estimates hepatic iron concentration in transfusion-dependent thalassemia and sickle cell disease patients. Blood. 2005 Aug 15;106(4):1460-5.

68. Carpenter J-P, He T, Kirk P, Roughton M, Anderson LJ, de Noronha SV, et al. On T2* magnetic resonance and cardiac iron. Circulation. 2011 Apr 12;123(14):1519-28.

69. Kirk P, Roughton M, Porter JB, Walker JM, Tanner MA, Patel J, et al. Cardiac T2* magnetic resonance for prediction of cardiac complications in thalassemia major. Circulation. 2009 Nov 17;120(20):1961-8.

70. Modell B, Khan M, Darlison M, Westwood MA, Ingram D, Pennell DJ. Improved survival of thalassaemia major in the UK and relation to T2* cardiovascular magnetic resonance. J Cardiovasc Magn Reson. 2008 Sep 25;10:42.

71. Baksi AJ, Pennell DJ. Randomized controlled trials of iron chelators for the treatment of cardiac siderosis in thalassaemia major. Front Pharmacol. 2014;5:217.

72. De Bruyne B, Pijls NHJ, Kalesan B, Barbato E, Tonino PAL, Piroth Z, et al.

Fractional Flow Reserve-Guided PCI versus Medical Therapy in Stable Coronary Disease. New England Journal of Medicine. 2012 Sep 13;367(11):991-1001.

73. Shaw LJ, Berman DS, Maron DJ, Mancini GBJ, Hayes SW, Hartigan PM, et al. Optimal medical therapy with or without percutaneous coronary intervention to reduce ischemic burden: results from the Clinical Outcomes Utilizing Revascularization and Aggressive Drug Evaluation (COURAGE) trial nuclear substudy. Circulation. 2008 Mar 11;117(10):1283-91. 74. Greenwood JP, Maredia N, Younger JF, Brown JM, Nixon J, Everett CC, et al. Cardiovascular magnetic resonance and single-photon emission computed tomography for diagnosis of coronary heart disease (CE-MARC): a prospective trial. Lancet. $2012 \mathrm{Feb}$ 4;379(9814):453-60. 
75. Schwitter J, Wacker CM, Wilke N, Al-Saadi N, Sauer E, Huettle K, et al. MR-IMPACT II: Magnetic Resonance Imaging for Myocardial Perfusion Assessment in Coronary artery disease Trial: perfusion-cardiac magnetic resonance vs. single-photon emission computed tomography for the detection of coronary artery disease: a comparative multicentre, multivendor trial. Eur Heart J. 2013 Mar;34(10):775-81. 76. Neglia D, Michelassi C, Trivieri MG, Sambuceti G, Giorgetti A, Pratali L, et al. Prognostic role of myocardial blood flow impairment in idiopathic left ventricular dysfunction. Circulation. 2002 Jan 15;105(2):186-93.

77. Cecchi F, Olivotto I, Gistri R, Lorenzoni R, Chiriatti G, Camici PG. Coronary microvascular dysfunction and prognosis in hypertrophic cardiomyopathy. N Engl J Med. 2003 Sep 11;349(11):1027-35.

78. Schwitter J, Nanz D, Kneifel S, Bertschinger K, Büchi M, Knüsel PR, et al. Assessment of myocardial perfusion in coronary artery disease by magnetic resonance: a comparison with positron emission tomography and coronary angiography. Circulation. 2001 May 8;103(18):2230-5.

79. Christian TF, Rettmann DW, Aletras AH, Liao SL, Taylor JL, Balaban RS, et al. Absolute Myocardial Perfusion in Canines Measured by Using Dual-Bolus First-Pass MR Imaging. Radiology. 2004 Sep 1;232(3):677-84.

80. Neimatallah MA, Chenevert TL, Carlos RC, Londy FJ, Dong Q, Prince MR, et al. Subclavian MR arteriography: reduction of susceptibility artifact with short echo time and dilute gadopentetate dimeglumine. Radiology. 2000 Nov;217(2):581-6.

81. Jerosch-Herold M, Wilke N, Stillman AE. Magnetic resonance quantification of the myocardial perfusion reserve with a Fermi function model for constrained deconvolution. Med Phys. 1998 Jan;25(1):73-84.

82. Christian TF, Aletras AH, Arai AE. Estimation of absolute myocardial blood flow during first-pass MR perfusion imaging using a dual-bolus injection technique: comparison to single-bolus injection method. J Magn Reson Imaging. 2008 Jun;27(6):1271-7.

83. Gatehouse PD, Elkington AG, Ablitt NA, Yang G-Z, Pennell DJ, Firmin DN. Accurate assessment of the arterial input function during high-dose myocardial perfusion cardiovascular magnetic resonance. J Magn Reson Imaging. 2004 Jul;20(1):39-45. 84. Mordini FE, Haddad T, Hsu L-Y, Kellman P, Lowrey TB, Aletras AH, et al. Diagnostic accuracy of stress perfusion CMR in comparison with quantitative coronary angiography: fully quantitative, semiquantitative, and qualitative assessment. JACC Cardiovasc Imaging. 2014 Jan;7(1):14-22.

85. Kellman P, Hansen MS, Nielles-Vallespin S, Nickander J, Themudo R, Ugander M, et al. Myocardial perfusion cardiovascular magnetic resonance: optimized dual sequence and reconstruction for quantification. Journal of Cardiovascular Magnetic Resonance. 2017;19(1):43.

86. Hansen MS, Sørensen TS. Gadgetron: an open source framework for medical image reconstruction. Magn Reson Med. 2013 Jun;69(6):1768-76.

87. Bassingthwaighte JB, Wang CY, Chan IS. Blood-tissue exchange via transport and transformation by capillary endothelial cells. Circ Res. 1989 Oct;65(4):997-1020.

88. Engblom H, Xue H, Akil S, Carlsson M, Hindorf C, Oddstig J, et al. Fully quantitative cardiovascular magnetic resonance myocardial perfusion ready for clinical use: a comparison between cardiovascular magnetic resonance imaging and positron emission tomography. Journal of Cardiovascular Magnetic Resonance. 2017 Oct 19;19:78.

89. Knott KD, Camaioni C, Ramasamy A, Augusto JA, Bhuva AN, Xue H, et al. Quantitative myocardial perfusion in coronary artery disease: A perfusion mapping study. J Magn Reson Imaging. 2019 Jan 25; 
90. Brown LAE, Onciul SC, Broadbent DA, Johnson K, Fent GJ, Foley JRJ, et al. Fully automated, inline quantification of myocardial blood flow with cardiovascular magnetic resonance: repeatability of measurements in healthy subjects. J Cardiovasc Magn Reson. 2018 Jul 9;20(1):48.

91. Kotecha T, Martinez-Naharro A, Boldrini M, Knight D, Hawkins P, Kalra S, et al. Automated Pixel-Wise Quantitative Myocardial Perfusion Mapping by CMR to Detect Obstructive Coronary Artery Disease and Coronary Microvascular Dysfunction: Validation Against Invasive Coronary Physiology. JACC Cardiovasc Imaging. 2019 Feb 11;

92. Hsu L-Y, Jacobs M, Benovoy M, Ta AD, Conn HM, Winkler S, et al. Diagnostic Performance of Fully Automated Pixel-Wise Quantitative Myocardial Perfusion Imaging by Cardiovascular Magnetic Resonance. JACC Cardiovasc Imaging. 2018 May;11(5):697-707. 93. Wong EC. Quantifying CBF with pulsed ASL: technical and pulse sequence factors. J Magn Reson Imaging. 2005 Dec;22(6):727-31.

94. Wolf RL, Detre JA. Clinical neuroimaging using arterial spin-labeled perfusion magnetic resonance imaging. Neurotherapeutics. 2007 Jul;4(3):346-59.

95. Kim SG. Quantification of relative cerebral blood flow change by flow-sensitive alternating inversion recovery (FAIR) technique: application to functional mapping. Magn Reson Med. 1995 Sep;34(3):293-301.

96. Belle V, Kahler E, Waller C, Rommel E, Voll S, Hiller KH, et al. In vivo quantitative mapping of cardiac perfusion in rats using a noninvasive MR spin-labeling method. J Magn Reson Imaging. 1998 Dec;8(6):1240-5.

97. Zun Z, Varadarajan P, Pai RG, Wong EC, Nayak KS. Arterial spin labeled CMR detects clinically relevant increase in myocardial blood flow with vasodilation. JACC Cardiovasc Imaging. 2011 Dec;4(12):1253-61.

98. Grothues F, Smith GC, Moon JCC, Bellenger NG, Collins P, Klein HU, et al. Comparison of interstudy reproducibility of cardiovascular magnetic resonance with two-dimensional echocardiography in normal subjects and in patients with heart failure or left ventricular hypertrophy. Am J Cardiol. 2002 Jul 1;90(1):29-34.

99. Moody WE, Edwards NC, Chue CD, Taylor RJ, Ferro CJ, Townend JN, et al. Variability in cardiac MR measurement of left ventricular ejection fraction, volumes and mass in healthy adults: defining a significant change at 1 year. Br J Radiol. 2015 May;88(1049):20140831. 100. Thavendiranathan P, Grant AD, Negishi T, Plana JC, Popović ZB, Marwick TH. Reproducibility of echocardiographic techniques for sequential assessment of left ventricular ejection fraction and volumes: application to patients undergoing cancer chemotherapy. J Am Coll Cardiol. 2013 Jan 8;61(1):77-84.

101. Kowallick JT, Staab W, Schuster A, Backhaus SJ, Weber-Krüger M, Bauer L, et al. Reverse left ventricular structural remodeling following catheter ablation of atrial fibrillation in patients with preserved left ventricular function: Insights from cardiovascular magnetic resonance native T1 mapping. Heart Rhythm. 2018 Sep 21. pii: S15475271(18)30939-1

102. Luetkens JA, Wolpers AC, Beiert T, Kuetting D, Dabir D, Homsi R, et al. Cardiac magnetic resonance using late gadolinium enhancement and atrial T1 mapping predicts poor outcome in patients with atrial fibrillation after catheter ablation therapy. Sci Rep. 2018 Sep 11;8(1):13618

103. Roller FC, Kriechbaum S, Breithecker A, Liebetrau C, Haas M, Schneider C, et al. Correlation of native T1 mapping with right ventricular function and pulmonary haemodynamics in patients with chronic thromboembolic pulmonary hypertension before and after balloon pulmonary angioplasty. Eur Radiol. 2018 Aug 29 
104. Chen R, Wang J, Du Z, Juan YH, Chan CW, Fei H, et al. The comparison of short-term prognostic value of T1 mapping with feature tracking by cardiovascular magnetic resonance in patients with severe dilated cardiomyopathy. Int J Cardiovasc Imaging. 2018 Aug 21 105. Pradella S, Grazzini G, Brandani M, Calistri L, Nardi C, Mori F, et al. Cardiac magnetic resonance in patients with mitral valve prolapse: Focus on late gadolinium enhancement and T1 mapping. Eur Radiol. 2018 Aug 7.

106. Takagi H, Ota H, Umezawa R, Kimura T, Kadoya N, Higuchi S, et al. Left Ventricular T1 Mapping during Chemotherapy-Radiation Therapy: Serial Assessment of Participants with Esophageal Cancer. Radiology. 2018 Jul 10:172076

107. Karur GR, Robison S, Iwanochko RM, Morel CF, Crean AM, Thavendiranathan P, et al. Use of Myocardial T1 Mapping at 3.0 T to Differentiate Anderson-Fabry Disease from Hypertrophic Cardiomyopathy. Radiology. 2018 Aug;288(2):398. 406.

108. Sade LE, Hazirolan T, Kozan H, Ozdemir H, Hayran M, Eroglu S, et al. T1 Mapping by Cardiac Magnetic Resonance and Multidimensional Speckle-Tracking Strain by

Echocardiography for the Detection of Acute Cellular Rejection in Cardiac Allograft Recipients. JACC Cardiovasc Imaging. 2018 Apr 14.

109. Muehlberg F, Funk S, Zange L, von Knobelsdorff-Brenkenhoff F, Blaszczyk E, Schulz A, et al. Native myocardial T1 time can predict development of subsequent anthracyclineinduced cardiomyopathy. ESC Heart Fail. 2018 Aug;5(4):620-629

110. Inui K, Asai K, Tachi M, Yoshinaga A, Izumi Y, Kubota Y, et al. Extracellular volume fraction assessed using cardiovascular magnetic resonance can predict improvement in left ventricular ejection fraction in patients with dilated cardiomyopathy. Heart Vessels. 2018 Oct;33(10):1195-1203

111. Martinez-Naharro A, Kotecha T, Norrington K, Boldrini M, Rezk T, Quarta C, et al. Native T1 and Extracellular Volume in Transthyretin Amyloidosis. JACC Cardiovasc Imaging. 2018 Mar 12

112. JAB Araujo-Filho, CR, Dantas RN Jr, Nomura CH, Salemi VMC, Jerosch-Herold M, Parga JR. Myocardial T1 mapping and extracellular volume quantification in patients with left ventricular non-compaction cardiomyopathy. Eur Heart J Cardiovasc Imaging. 2018 Aug 1;19(8):888-895

113. Yanagisawa F, Amano Y, Tachi M, Inui K, Asai K, Kumita S. Non-contrast-enhanced T1 Mapping of Dilated Cardiomyopathy: Comparison between Native T1 Values and Late Gadolinium Enhancement. Magn Reson Med Sci. 2018 Mar 7

114. Torlasco C, Cassinerio E, Roghi A, Faini A, Capecchi M, Abdel-Gadir A, et al. Role of T1 mapping as a complementary tool to $\mathrm{T} 2 *$ for non-invasive cardiac iron overload assessment. PLoS One. 2018 Feb 21

115. Puntmann VO, Carr-White G, Jabbour A, Yu CY, Gebker R, Kelle S, et al International T1 Multicentre CMR Outcome Study. Native T1 and ECV of Noninfarcted Myocardium and Outcome in Patients With Coronary Artery Disease. J Am Coll Cardiol. 2018 Feb 20;71(7):766-778

116. Yu L, Sun J, Li J, Dong Y, Zhou X, Greiser A et al.. Early detection of myocardial involvement by T1 mapping of cardiac MRI in idiopathic inflammatory myopathy. J Magn Reson Imaging. 2018 Aug;48(2):415-422.

117. Lin L, Li X, Feng J, Shen KN, Tian Z, Sun J, et al. The prognostic value of T1 mapping and late gadolinium enhancement cardiovascular magnetic resonance imaging in patients with light chain amyloidosis. J Cardiovasc Magn Reson. 2018 Jan 3;20(1):2.

118. Reinstadler SJ, Stiermaier T, Liebetrau J, Fuernau G, Eitel C, de Waha S, et al. Prognostic Significance of Remote Myocardium Alterations Assessed by Quantitative Noncontrast T1 Mapping in ST-Segment Elevation Myocardial Infarction. JACC Cardiovasc 
Imaging. 2018 Mar;11(3):411-9.

119. Lee H, Park J-B, Yoon YE, Park E-A, Kim H-K, Lee W, et al. Noncontrast Myocardial T1 Mapping by Cardiac Magnetic Resonance Predicts Outcome in Patients With Aortic Stenosis. JACC Cardiovasc Imaging. 2018 Jul;11(7):974-83.

120. Nakamori S, Dohi K, Ishida M, Goto Y, Imanaka-Yoshida K, Omori T, et al. Native T1 Mapping and Extracellular Volume Mapping for the Assessment of Diffuse Myocardial Fibrosis in Dilated Cardiomyopathy. JACC Cardiovasc Imaging. 2018 Jan;11(1):48-59.

121. Cui Y, Cao Y, Song J, Dong N, Kong X, Wang J, et al. Association between myocardial extracellular volume and strain analysis through cardiovascular magnetic resonance with histological myocardial fibrosis in patients awaiting heart transplantation. J Cardiovasc Magn Reson. 2018 Apr 23;20(1):25

122. Jellis CL, Yingchoncharoen T, Gai N, Kusunose K, Popović ZB, Flamm S, et al. Correlation between right ventricular T1 mapping and right ventricular dysfunction in nonischemic cardiomyopathy. Int J Cardiovasc Imaging. 2018 Jan;34(1):55-65.

123. Guo Q, Wu LM, Wang Z, Shen JY, Su X, Wang CQ, et al. Early Detection of Silent Myocardial Impairment in Patients with New Onset Drug-Naïve Systemic Lupus Erythematosus - A Three-Center Prospective Study (Myocardial Impairment in New Onset SLE). Arthritis Rheumatol. 2018 Aug 2.

124. Mordi IR, Singh S, Rudd A, Srinivasan J, Frenneaux M, Tzemos N, et al. Comprehensive Echocardiographic and Cardiac Magnetic Resonance Evaluation Differentiates Among Heart Failure With Preserved Ejection Fraction Patients, Hypertensive Patients, and Healthy Control Subjects. JACC Cardiovasc Imaging. 2018 Apr;11(4):577-585

125. Ridouani F, Damy T, Tacher V, Derbel H, Legou F, Sifaoui I, et al. Myocardial native T2 measurement to differentiate light-chain and transthyretin cardiac amyloidosis and assess prognosis. J Cardiovasc Magn Reson. 2018 Aug 16;20(1):58

126. Kotecha T, Martinez-Naharro A, Treibel TA, Francis R, Nordin S, Abdel-Gadir A, et al. Myocardial Edema and Prognosis in Amyloidosis. J Am Coll Cardiol. 2018 Jun 26;71(25):2919-2931

127. Wang J, Zhao H, Wang Y, Herrmann HC, Witschey WRT, et al. Native T1 and T2 mapping by cardiovascular magnetic resonance imaging in pressure overloaded left and right heart diseases. J Thorac Dis. 2018 May;10(5):2968-2975.

128. Gastl M, Behm P, Haberkorn S, Holzbach L, Veulemans V, Jacoby C, et al. Role of T2 mapping in left ventricular reverse remodeling after TAVR. Int J Cardiol. 2018 Sep 1;266:262-268.

129. Tessa C, Del Meglio J, Lilli A, Diciotti S, Salvatori L, Giannelli M, et al. T1 and T2 mapping in the identification of acute myocardial injury in patients with NSTEMI. Radiol Med. 2018 Aug 21 


\section{Tables:}

Table 1. Minimal detectable changes (MDC)* - a precision measurement - of left ventricular parameters using cardiovascular magnetic resonance (CMR) compared to 2D and 3D echocardiography.

\section{Minimal detectable changes in left ventricular parameters}

\begin{tabular}{|c|c|c|c|c|}
\hline \multicolumn{3}{|c|}{ Immediate rescan interval } & \multicolumn{2}{|c|}{ One- year rescan interval } \\
\hline Modality & CMR & 2D Echo & CMR & 3D Echo \\
\hline Study & Grothues et al (98) & Grothues et al (98) & Moody et al (99) & Thavendiranathan et al (100) \\
\hline Study date & 2002 & 2002 & 2015 & 2013 \\
\hline Sample size & 60 & 60 & 42 & 56 \\
\hline Population & $\begin{array}{l}\text { Heart failure } \\
\text { LVH } \\
\text { Healthy volunteers }\end{array}$ & $\begin{array}{l}\text { Heart failure } \\
\text { LVH } \\
\text { Healthy volunteers }\end{array}$ & Healthy volunteers & Cardio-oncology (normal EF) \\
\hline EF (\%) & 4 & 12 & 5.8 & 6.0 \\
\hline $\operatorname{Mass}(\mathrm{g})^{* *}$ & 15 & 49 & 5.9 & - \\
\hline EDV (mls) & 13 & 26 & 12.7 & 34.8 \\
\hline ESV (mls) & 11 & 27 & 7.2 & 13.9 \\
\hline SV (mls) & 10 & 26 & - & 14 \\
\hline
\end{tabular}


Table 2. Recent studies evaluating the role of T1 mapping and ECV in various cardiac disease models

\begin{tabular}{|c|c|c|c|c|c|c|}
\hline Authors, & $\begin{array}{l}\text { Year of } \\
\text { publication }\end{array}$ & $\begin{array}{l}\text { Disease/ Pathology being } \\
\text { investigated }\end{array}$ & $\begin{array}{l}\text { Number of } \\
\text { patients/ } \\
\text { controls }\end{array}$ & $\begin{array}{l}\text { Field } \\
\text { Strength } \\
(\mathrm{T})\end{array}$ & $\begin{array}{l}\text { T1 mapping } \\
\text { sequence }\end{array}$ & Outcome/Conclusion \\
\hline $\begin{array}{l}\text { Kowallick et } \\
\text { al, (101) }\end{array}$ & 2018 & Atrial fibrillation $(\mathrm{AF})$ & $\begin{array}{l}43 \text { patients } \\
22 \text { controls }\end{array}$ & 3 & MOLLI & $\begin{array}{l}\text { Higher native myocardial } \mathrm{T} 1 \text { values in patients with } \mathrm{AF} \text {, reduced 3-months post } \mathrm{AF} \\
\text { ablation }\end{array}$ \\
\hline $\begin{array}{l}\text { Luetkens et } \\
\text { al, (102) }\end{array}$ & 2018 & Atrial fibrillation $(\mathrm{AF})$ & 61 patients & 1.5 & MOLLI & Atrial T1 value predictor of poor outcomes post ablation \\
\hline $\begin{array}{l}\text { Roller et al, } \\
\text { (103) }\end{array}$ & 2018 & $\begin{array}{l}\text { Chronic thromboembolic } \\
\text { pulmonary hypertension }\end{array}$ & 21 patients & 1.5 & MOLLI & $\begin{array}{l}\text { Native T1 mapping indicative of reverse myocardial tissue remodeling after balloon } \\
\text { pulmonary angioplasty }\end{array}$ \\
\hline $\begin{array}{l}\text { Chen et al, } \\
\text { (104) }\end{array}$ & 2018 & $\begin{array}{l}\text { Dilated cardiomyopathy } \\
\text { (DCM) }\end{array}$ & 46 patients & 3 & MOLLI & $\begin{array}{l}\text { Post-contrast T1 calculated ECV was a strong predictor of adverse cardiovascular } \\
\text { events in patients with severe DCM }\end{array}$ \\
\hline $\begin{array}{l}\text { Pradella et al, } \\
\text { (105) }\end{array}$ & 2018 & Mitral valve prolapse (MVP) & 34 patients & 1.5 & MOLLI & $\begin{array}{l}\text { Higher native T1-values, lower post-contrast T1-values and increased ECV-values in } \\
\text { patients with MVP }\end{array}$ \\
\hline $\begin{array}{l}\text { Tagaki et al, } \\
\text { (106) }\end{array}$ & 2018 & $\begin{array}{l}\text { Chemotherapy } \\
\text { radiotherapy } \\
\text { cardiotoxicity }\end{array}$ & 14 patients & 3 & MOLLI & T1 mapping detects early changes post therapy in cancer patients \\
\hline $\begin{array}{l}\text { Karur et al, } \\
(107)\end{array}$ & 2018 & $\begin{array}{l}\text { Anderson-Fabry disease } \\
\text { (AFD), Hypertrophic } \\
\text { cardiomyopathy (HCM) }\end{array}$ & $\begin{array}{l}30-\mathrm{HCM} \\
30-\mathrm{AFD}\end{array}$ & 3 & MOLLI & $\begin{array}{l}\text { T1 mapping can provide independent and incremental diagnostic value in } \\
\text { differentiating the two conditions }\end{array}$ \\
\hline $\begin{array}{l}\text { Sade et al, } \\
(108)\end{array}$ & 2018 & $\begin{array}{lr}\text { Acute cellular } & \text { rejection in } \\
\text { cardiac } & \text { transplant } \\
\text { recipients } & \end{array}$ & 38 patients & 1.5 & MOLLI & $\begin{array}{l}\text { T1 mapping can serve to guide endomyocardial biopsy (EMB) in patients with } \\
\text { suspected allograft rejection }\end{array}$ \\
\hline $\begin{array}{l}\text { Muehlberg et } \\
\text { al, (109) }\end{array}$ & 2018 & $\begin{array}{l}\text { Anthracycline-based } \\
\text { chemotherapy }\end{array}$ & 30 patients & 1.5 & MOLLI & Early decrease of T1 times can predict the development of subsequent cardio-toxicity \\
\hline $\begin{array}{l}\text { Inui et al, } \\
\text { (110) }\end{array}$ & 2018 & $\begin{array}{l}\text { Dilated Cardiomyopathy } \\
\text { (DCM) }\end{array}$ & 33 patients & 3 & MOLLI & ECV can predict improvements in LVEF in patients with DCM \\
\hline $\begin{array}{l}\text { Martinez- } \\
\text { Naharro et al, } \\
\text { (111) }\end{array}$ & 2018 & $\begin{array}{l}\text { Transthyretin Amyloidosis } \\
\text { (ATTR) }\end{array}$ & 271 patients & 1.5 & MOLLI & $\begin{array}{l}\text { Native T1 mapping and ECV are good diagnostic techniques for cardiac ATTR that are } \\
\text { associated with prognosis }\end{array}$ \\
\hline $\begin{array}{l}\text { Araujo-Filho } \\
\text { et al, (112) }\end{array}$ & 2018 & $\begin{array}{l}\text { Left ventricular non- } \\
\text { compaction } \\
\text { cardiomyopathy (LVNC) }\end{array}$ & $\begin{array}{l}36 \text { patients } \\
18 \text { controls }\end{array}$ & 1.5 & MOLLI & Patients with LVNC showed increased ECV and native T1 compared with controls \\
\hline
\end{tabular}




\begin{tabular}{|c|c|c|c|c|c|}
\hline $\begin{array}{l}\text { Yanagisawa } \\
\text { et al, (113) }\end{array}$ & DCM & $\begin{array}{l}25 \text { patients } \\
15 \text { controls }\end{array}$ & 1.5 & MOLLI & T1 mapping can be used for assessment of myocardial fibrosis associated with DCM \\
\hline $\begin{array}{l}\text { Torlasco et al, } \\
\text { (114) }\end{array}$ & $\begin{array}{ll}\text { Iron } & \text { overload/ } \\
\text { Thalassaemia } & \end{array}$ & $\begin{array}{l}138 \text { patients } \\
32 \text { controls }\end{array}$ & 1.5 & MOLLI & T1 mapping is complementary to $\mathrm{T} 2 *$ in detecting cardiac iron overload \\
\hline $\begin{array}{l}\text { Puntmann } \\
\text { al, (115) }\end{array}$ & Coronary artery disease & 665 patients & $1.5 / 3$ & MOLLI & $\begin{array}{l}\text { T1 is an important predictor of outcome in CAD patients, over and above the } \\
\text { traditional risk stratifiers }\end{array}$ \\
\hline Yu et al, (116) & $\begin{array}{l}\text { Dermatomyositis (DM) } \\
\text { Polymyositis (PM) }\end{array}$ & $\begin{array}{l}25 \text { patients } \\
25 \text { controls }\end{array}$ & 1.5 & MOLLI & T1 mapping detects subclinical myocardial involvement in PM/DM patients \\
\hline $\begin{array}{l}\text { Lin et al, } 2018 \\
(117)\end{array}$ & $\begin{array}{l}\text { Light chain amyloidosis } \\
\text { (AL) }\end{array}$ & $\begin{array}{l}82 \text { patients } \\
20 \text { controls }\end{array}$ & 3 & MOLLI & ECV (post-contrast T1) independently prognostic for mortality in AL amyloidosis \\
\hline $\begin{array}{l}\text { Reinstadler et } 2018 \\
\text { al, (118) }\end{array}$ & ST elevation MI (STEMI) & 255 patients & 1.5 & MOLLI & $\begin{array}{l}\text { Increased remote zone native T1 values were associated with worse clinical outcomes } \\
\text { post STEMI. }\end{array}$ \\
\hline $\begin{array}{l}\text { Lee et al, } 2018 \\
\text { (119) }\end{array}$ & Aortic stenosis & $\begin{array}{l}127 \text { patients } \\
33 \text { controls }\end{array}$ & 3 & MOLLI & $\begin{array}{l}\text { T1 value on noncontrast T1 mapping CMR is a novel, independent predictor of adverse } \\
\text { outcome in patients with significant AS. }\end{array}$ \\
\hline Vita et al, (51) 2018 & $\begin{array}{l}\text { Dilated } \\
\text { (DCM) }\end{array}$ & 240 patients & 3 & $\begin{array}{l}\text { cine Look- } \\
\text { Locker }\end{array}$ & $\begin{array}{l}\text { ECV offers improved prognostication in patients with DCM compared to LGE or native } \\
\text { T1 mapping. }\end{array}$ \\
\hline $\begin{array}{l}\text { Nakamori et } 2018 \\
\text { al, (120) }\end{array}$ & $\begin{array}{ll}\begin{array}{l}\text { Dilated } \\
\text { (DCM) }\end{array} & \text { Cardiomyopathy } \\
\end{array}$ & 36 patients & 3 & MOLLI & Diffuse myocardial fibrosis in DCM may be reliably assessed by native T1 mapping \\
\hline $\begin{array}{l}\text { Cui et al, } 2018 \\
\text { (121) }\end{array}$ & $\begin{array}{l}\text { End-stage ischaemic and } \\
\text { dilated cardiomyopathy }\end{array}$ & 22 patients & 1.5 & MOLLI & $\begin{array}{l}\text { ECV derived from cardiac MRI correlated well with histological collagen volume } \\
\text { fraction in patients undergoing transplant due to ischaemic or dilated cardiomyopathy. }\end{array}$ \\
\hline $\begin{array}{l}\text { Jellis } \\
\text { (122) }\end{array}$ & RV function & 102 patients & 1.5 & $\begin{array}{l}\text { Inversion } \\
\text { recovery Look- } \\
\text { Locker }\end{array}$ & $\begin{array}{l}\text { Post-contrast T1 mapping provides incremental information regarding global RV } \\
\text { function and structure }\end{array}$ \\
\hline $\begin{array}{llll}\text { Guo } & \text { et } & \text { al, } & 2018 \\
(\mathbf{1 2 3}) & & \end{array}$ & $\begin{array}{l}\text { Systemic } \\
\text { Erythematosus (SLE) }\end{array}$ & $\begin{array}{l}110 \text { patients } \\
50 \text { controls }\end{array}$ & 3 & MOLLI & $\begin{array}{l}\text { Native myocardial T1 values and ECV, rather than current clinical rheumatic and } \\
\text { cardiac indices, could serve as early detection markers of myocardial injury in patients } \\
\text { with SLE }\end{array}$ \\
\hline $\begin{array}{l}\text { Mordi et al, } 2018 \\
\text { (124) }\end{array}$ & $\begin{array}{l}\text { Hypertensive heart disease } \\
\text { and Heart failure with } \\
\text { preserved ejection fraction } \\
\text { (HFpEF) }\end{array}$ & $\begin{array}{l}84 \text { patients } \\
28 \text { controls }\end{array}$ & 3 & MOLLI & $\begin{array}{l}\text { ECV is the strongest imaging diagnostic marker for independently differentiating } \\
\text { between hypertensive heart disease and HFpEF. }\end{array}$ \\
\hline \multicolumn{6}{|c|}{$\begin{array}{l}\text { AF - atrial fibrillation; DCM - dilated cardiomyopathy; MVP - mitral valve prolapse; AFD - Anderson-Fabry disease; hypertrophic cardiomyopathy - HCM; ATTR - transthyretin amyloidosis; DM } \\
\text { Dermatomyositis ; PM - Polymyositis; AL - light chain amyloidosis; STEMI - ST elevation myocardial infarction; AS - Aortic stenosis; LVNC - Left ventricular non-compaction cardiomyopathy; SLE } \\
\text { Systemic Lupus Erythematosus; HFpEF - Heart failure with preserved ejection fraction; ECV - extracellular volume fraction; RV - right ventricle; CAD - coronary artery disease; LGE - late gadolinium } \\
\text { enhancement; EBM - endomyocardial biopsy }\end{array}$} \\
\hline
\end{tabular}


Table 3. Recent studies evaluating the role of $\mathrm{T} 2$ in cardiac disease

\begin{tabular}{|c|c|c|c|c|c|c|}
\hline Authors & Year & $\begin{array}{l}\text { Disease/ Pathology being } \\
\text { investigated }\end{array}$ & $\begin{array}{l}\text { Number of } \\
\text { patients/ } \\
\text { controls }\end{array}$ & $\begin{array}{l}\text { Field } \\
\text { Strength } \\
(\mathrm{T})\end{array}$ & T2 mapping sequence & Outcome/Conclusion \\
\hline $\begin{array}{l}\text { Vermes et al } \\
\text { (57) }\end{array}$ & 2018 & $\begin{array}{l}\text { Acute rejection in cardiac } \\
\text { transplant patients }\end{array}$ & 20 patients & 1.5 & T2-prepared bSSFP sequence & $\begin{array}{l}\text { A combined CMR approach using T2 mapping and ECV quantification } \\
\text { could potentially decrease the number of routine endomyocardial biopsies } \\
\text { performed to diagnose acute rejection }\end{array}$ \\
\hline $\begin{array}{l}\text { Spieker et al } \\
(58)\end{array}$ & 2018 & $\begin{array}{l}\text { Dilated cardiomyopathy } \\
\text { (DCM) }\end{array}$ & $\begin{array}{l}70 \text { patients } \\
62 \text { controls }\end{array}$ & 1.5 & Gradient Spin Echo (GraSE) & $\begin{array}{l}\text { Myocardial T2 relaxation times may help to non-invasively detect } \\
\text { myocardial inflammation }\end{array}$ \\
\hline $\begin{array}{l}\text { Winau et aL } \\
\text { (60) }\end{array}$ & 2018 & $\begin{array}{l}\text { Systemic Lupus } \\
\text { Erythematosus (SLE) }\end{array}$ & 92 patients & 3 & $\begin{array}{l}\text { Gradient and spin echo } \\
\text { (GraSE) sequence/Fast low } \\
\text { angle shot (FLASH) sequence }\end{array}$ & $\begin{array}{l}\text { CMR with T2 mapping reveals myocardial oedema as the strongest } \\
\text { predictor of hs-TropT release }\end{array}$ \\
\hline $\begin{array}{l}\text { Fehrmann } \\
\text { et al (61) }\end{array}$ & 2018 & Aortic stenosis (AS) & $\begin{array}{l}72 \text { patients } \\
27 \text { controls }\end{array}$ & 3 & Gradient Spin Echo (GraSE) & $\begin{array}{l}\text { Mean myocardial T2 was significantly elevated in AS patients pointing } \\
\text { towards a potential role of oedematous/inflammatory processes in the } \\
\text { pathophysiology of myocardial remodelling associated with AS }\end{array}$ \\
\hline $\begin{array}{l}\text { Kvernby et } \\
\text { al (62) }\end{array}$ & 2018 & Aortic stenosis (AS) & 15 patients & 3 & Gradient Spin Echo (GraSE) & $\begin{array}{l}\text { T1 and T2 relaxation times related to diffuse myocardial fibrosis in aortic } \\
\text { stenosis }\end{array}$ \\
\hline $\begin{array}{l}\text { Haslbauer } \\
\text { et al (64) }\end{array}$ & 2018 & $\begin{array}{l}\text { Cardio-toxicity from cancer } \\
\text { related treatment }\end{array}$ & $\begin{array}{l}115 \text { patients } \\
57 \text { controls }\end{array}$ & 3 & $\begin{array}{l}\text { T2- Gradient Spin Echo } \\
\text { (GraSE) } \\
\text { T2-FLASH }\end{array}$ & $\begin{array}{l}\mathrm{T} 1 \text { and } \mathrm{T} 2 \text { mapping can demonstrate distinct biosignatures of early and } \\
\text { late myocardial cardio-toxicty. }\end{array}$ \\
\hline $\begin{array}{l}\text { Ridouani et } \\
\text { al (125) }\end{array}$ & 2018 & Cardiac amyloidosis & $\begin{array}{l}44 \text { patients } \\
40 \text { controls }\end{array}$ & 1.5 & $\begin{array}{l}\text { bSSFP sequence with an } \\
\text { adiabatic T2 preparation }\end{array}$ & $\begin{array}{l}\text { Myocardial native T2 significantly is increased in cardiac amyloidosis, with } \\
\text { greater increase seen in AL patients in comparison to ATTR patients }\end{array}$ \\
\hline $\begin{array}{l}\text { Kotecha et } \\
\text { al (126) }\end{array}$ & 2018 & $\begin{array}{lr}\text { Light-chain } & \text { (AL) } \begin{array}{r}\text { and } \\
\text { Transthyretin }\end{array} \\
\text { Amyloidosis } & \text { (ATTR) } \\
\end{array}$ & $\begin{array}{l}286 \text { patients } \\
30 \text { controls }\end{array}$ & 1.5 & T2-prepared SSFP sequence & $\begin{array}{l}\text { T2 is higher in untreated AL amyloidosis compared with treated AL and } \\
\text { ATTR amyloidosis, and is a predictor of prognosis in AL amyloidosis }\end{array}$ \\
\hline $\begin{array}{l}\text { Wang et al } \\
\text { (127) }\end{array}$ & 2018 & $\begin{array}{l}\text { Pulmonary } \text { Hypertension } \\
\text { (PHT) and severe aortic } \\
\text { stenosis (AS) }\end{array}$ & $\begin{array}{l}18 \text {-patients } \\
\text { with PHT } \\
\text { 19- patients } \\
\text { with AS }\end{array}$ & 1.5 & T2-prepared SSFP sequence & $\begin{array}{l}\text { T2 values correlated with structural and functional remodeling in both } \\
\text { diseases. }\end{array}$ \\
\hline $\begin{array}{l}\text { Gastl et al } \\
(128)\end{array}$ & 2018 & Aortic stenosis (AS) & 43 patients & 1.5 & Gradient Spin Echo (GraSE) & $\begin{array}{l}\text { T2 mapping can be used to characterize myocardial hypertrophy due to } \\
\text { severe AS and to monitor myocardial adaptations after transcatheter } \\
\text { aortic valve replacement. }\end{array}$ \\
\hline $\begin{array}{l}\text { Tessa et al } \\
(129)\end{array}$ & 2018 & $\begin{array}{r}\text { elevation } \\
\text { infarction }\end{array}$ & 47 patients & 1.5 & $\begin{array}{l}\text { T2-prepared } \\
\text { sequence }\end{array}$ & $\begin{array}{l}\text { T1 and T2 mapping detect myocardial edema without significant stenosis } \\
\text { at CA and vice versa }\end{array}$ \\
\hline
\end{tabular}




\section{Figure Legends:}

Figure 1. Illustration of Al-derived left ventricular endocardial segmentation in endsystolic short-axis images (2D steady-state free procession acquisition). Endocardial contours are shown in red. Source: J.A. and J.M, data to be published.

Figure 2. Cardiac MRI feature tracking in a patient with Fabry disease. Endocardial and epicardial borders are drawn on short-axis and long-axis. (A) and (B) show short-axis radial strain in end-diastole (ED) and end-systole (ES), respectively. The bullseye 16segment model (American Heart Association) is derived (C). A graph of radial myocardial strain throughout the cardiac cycle is shown (D). Circumferential (E, F, G and H) and longitudinal strain (I, J, K and L) analyses are also shown. Of note, peak longitudinal strain $(\mathrm{J}$ and $\mathrm{K})$ was reduced in the mid inferolateral, lateral and anterior segments despite the absence of hypertrophy or scar - suggesting early disease detection. All analyses were performed in CVI42 software (Circle Cardiovascular Imaging, Calgary, Canada).

Figure 3. Articles related to T1 mapping using CMR. Search performed on Pubmed on the $4^{\text {th }}$ of February 2019. (T1 and MAPPING) AND ("heart"[MeSH Terms] OR "heart" OR "cardiac"). Titles and abstracts were reviewed to ensure relevance to cardiac magnetic resonance imaging and T1 mapping. ${ }^{*}$ Includes both original research and review articles.

Figure 4. T1, T2 and ECV (left to right) maps for (top to bottom) (A) a healthy control, (B) patient with myocarditis, (C) patient with Fabry disease and (D) a patient with amyloid. The color look up tables of the parametric maps allow visual interpretation. The healthy control shows normal T1 $(990 \mathrm{~ms})$, T2 $(48 \mathrm{~ms})$ and ECV (26\%). In myocarditis (B) the basal lateral wall has high T1 $(1200 \mathrm{~ms})$, T2 $(61 \mathrm{~ms})$ and ECV $(50 \%)$. In Fabry (C) the lateral wall is similar (T1 $1220 \mathrm{~ms}$, T2 $62 \mathrm{~ms}$ and ECV $55 \%$ ), but there is remote T1 lowering (820ms) and hypertrophy. In amyloid (D) there is mild LVH and globally elevated T1 $(1130 \mathrm{~ms})$ which is particularly high in the lateral wall $(1230 \mathrm{~ms})$ in this case, T2 is mildly elevated in the lateral wall (55ms) and global ECV is high (44\%) - a value beyond that possible in global diffuse fibrosis.

Figure 5: $\mathrm{T}_{1}, \mathrm{~T}^{*}$ and $\mathrm{R}^{*}$ (relaxation rate) maps (left to right) in a patient with severe cardiac iron overload (B) and in a healthy control (A). In cardiac overload the T1 mapping value $(650 \mathrm{~ms})$ and $\mathrm{T}^{*}(9.8 \mathrm{~ms})$ are low, whereas the relaxation rate $\left(\mathrm{R} 2^{*}\right)$ is elevated $(99 \mathrm{~Hz})$.

Figure 6. Basal, mid and apical slices for a patient with severe right coronary artery disease. There are standard perfusion images (A\&B) and quantitative perfusion maps (C\&D). Vasodilator stress perfusion (A\&C) and rest perfusion (B\&D). On the perfusion maps, the myocardial blood flow in the area of hypoperfusion is $0.65 \mathrm{ml} / \mathrm{g} / \mathrm{min}$ compared to $2.95 \mathrm{ml} / \mathrm{g} / \mathrm{min}$ in the remote myocardium. Rest myocardial blood flow is $1.00 \mathrm{ml} / \mathrm{g} / \mathrm{min}$.

Figure 7. Quantitative perfusion maps for a patient with apical hypertrophic cardiomyopathy. The vasodilator stress maps (A) demonstrate hypoperfusion in the hypertrophied apex and basal anteroseptum. Remote myocardium has a myocardial blood flow (MBF) of $1.71 \mathrm{ml} / \mathrm{g} / \mathrm{min}$, hypoperfused myocardium has an MBF of $0.46 \mathrm{ml} / \mathrm{g} / \mathrm{min}$. Rest shows homogenous flow with an MBF $1.08 \mathrm{ml} / \mathrm{g} / \mathrm{min}$. Therefore flow has fallen at peak stress. 